\title{
Analysis of the Quality Parameter Requirements of National Standard Development for Battery Swap in Electric Vehicles
}

\author{
Widia Citra Anggundari ${ }^{1, a}$, Auraga Dewantoro ${ }^{2, a}$, Bendjamin B.L..$^{3, a}$, Rika Dwi Susmiarni ${ }^{4}$, Yopi $^{5}$, Nur \\ Tjahyo Eka Darmayanti ${ }^{6}$ \\ 1,2,3,4,5,6 Center of Research and Human Resources Development, National Standardization Agency of Indonesia (BSN) \\ Tangerang Selatan, Banten, 15314, Indonesia \\ aThese authors contributed equally to this work
}

\begin{tabular}{l} 
Article Info \\
\hline Article history: \\
Received Sep 3, 2020 \\
Revised Dec 17, 2020 \\
Accepted Jan 2, 2021 \\
\hline
\end{tabular}

Keywords:

Battery swap

Electrical vehicle

Indonesia National Standard

Parameter

\begin{abstract}
The electric vehicle industry is expected to increase from year to year. Electric vehicles used energy stored in battery packs. The battery requires a long energy charge when the energy in the battery runs out. The solution to this energy charging time is a battery swap system. The purpose of this study was to analyze the parameters of the quality requirements for the development of a national standard battery for electric vehicles. The sampling method was carried out by non-probability sampling with a purposive sampling method. Respondents consist of various types of stakeholders who are directly related to electric vehicles so that this approach is expected to be able to answer the needs of the standard parameters of electric vehicle swap batteries in Indonesia. Data were analyzed using descriptive analysis. Based on the research results obtained several parameters, namely the type of battery, battery size and dimensions, security system requirements, communication, protection against electric shock, equipment construction requirements, electromagnetic compatibility, and marking and instructions. It is expected that these parameters can be taken into consideration for inclusion in the Indonesian National Standard governing battery swap in electric vehicles.
\end{abstract}

Copyright $(2021$ Institute of Advanced Engineering and Science. All rights reserved.

\section{Corresponding Author:}

Widia Citra Anggundari,

Center of Research and Human Resources Development,

National Standardization Agency of Indonesia,

Building 430, Kawasan Puspiptek, Muncul, Setu, South Tangerang City, Banten.

Email: widiacitra@bsn.go.id

\section{INTRODUCTION}

The electric vehicle industry is increasing from year to year. The share of the electric vehicle (EV) market is expected to grow from around 1\% to around 30\% in Europe and around 15\% in the US in 2025, totaling 130 million by 2030 globally [1]. The increase in the electric vehicle industry is accompanied by the awareness that there has been an increase in emissions of gases that are harmful to the environment, as well as a reduction in natural resources in the world. Electric vehicles are one of the most effective ways to reduce petroleum consumption [2]. Compared to petroleum-fueled vehicles, electric vehicles have low engine noise levels and high energy efficiency [3]. Electric vehicles are a good form of transportation as a substitute for fueled vehicles because they do not produce emissions and are environmentally friendly. The development of electric vehicles will not only help reduce carbon emissions from the transportation sector but will also support the development of electrical installations [4].

Electric vehicles use energy stored in battery packs. The battery is a storage medium consisting of two electrodes on an electrolyte. These electrolytes provide a medium for ion exchange which generates electricity [5]. When the battery is connected to an external circuit, the electrolyte will move as ions and a chemical reaction occurs at both poles. The movement of ions in the battery will drain the electric current out of the battery so that it produces work [6]. The battery will determine the mileage of an electric vehicle. 
One of the electric vehicles that are widely developed today is an electric motorcycle. Electric motorbikes are expected to replace motorcycles that run on oil. Motorbikes as a means of personal transportation have the highest percentage of inter-city transportation in Indonesia [7]. The following is data from the Indonesia's Central Statistics Agency (BPS) regarding the number of various vehicles in the last five years, starting from 2014 to 2018. According to data from the Central Statistics Agency, the number of motorbikes in 2018 reached 120,101,047 and the number of passenger cars was 16,440,987 vehicles (Figure 1). This data is the latest data released by the Statistics Indonesia and no latest data explains the number of vehicles in 2020, but according to data from the Association of Indonesian Automotive Industries (Gaikindo) in 2019 , there was an increase in the number of motorized vehicles, as many as 1,043,017 units.

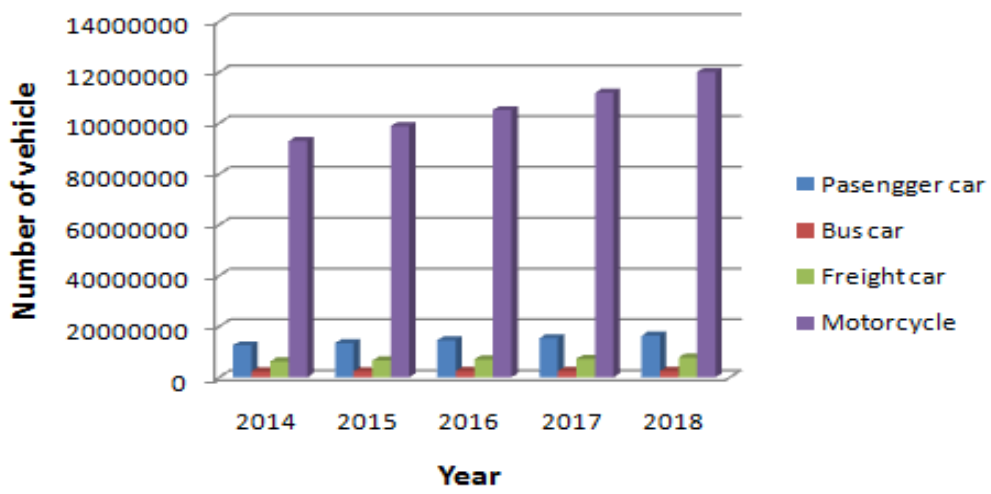

Figure 1. Number of motorized vehicles in 2014-2018 [8]

The number of motorized vehicles is estimated to continue to increase from year to year and electric vehicles are the solution to this problem. Electric vehicles use energy stored in the form of batteries, and batteries require a process of charging energy. The main drawback of all-electric vehicles or electric motorbikes is the charging time. To overcome this, one of the most efficient and hassle-free time charging methods is the technique of swapping batteries or using swap batteries [4]. A battery swap can provide a new battery that is fully charged so it does not take too long to charge the battery. The anxiety will be reduced, and to some extent, the distance can be covered [9].

The swap battery system has the advantage of fast battery replacement because it cuts the need for battery charging time. A fast-filling process is needed because customers do not want to wait long and the accumulation of filling also has an impact on the overload saving aspects of the filling station. This battery swap system is also important in wide-scale applications, especially on long distance trips that exceed the battery capacity. Users can swap batteries at the Battery Swap Station (BSS). BSS is very similar to the current fuel filling station, except that there is battery exchange [10].

Current vehicle battery exchange systems and infrastructure are mainly based on battery exchange stations and battery charging plants. The battery exchange station has two main functions namely to provide battery exchange services for electric vehicle users directly and to recharge the batteries to provide indirect battery exchange services for EV users [10]. The battery exchange station consists of mechanical and structural components as well as electrical components [11].

Currently in Indonesia, no standard can facilitate the use of swap batteries in electric vehicles. These standards are needed to ensure the quality of the batteries to be exchanged. Standards must include parameters that are following existing needs, so it is necessary to develop an Indonesian National Standard related to the parameters of the quality requirements for electric vehicle swap batteries. To answer this problem, this study uses a direct approach to stakeholders associated with electric vehicles so this study it is hoped that the proposed parameters can match Indonesia's needs in developing swap batteries in electric vehicles. The purpose of this research is to analyze the parameters of the swap battery quality requirements in electric vehicles.

\section{RESEARCH METHOD}

\subsection{Methods}

This study uses primary data and secondary data. The selection of samples or respondents was carried out using a non-probability sampling method with a purposive sampling method, namely sampling based on the expertise of the subject under study, in this case the swap battery in electric vehicles. Primary data were obtained from the results of a survey using a questionnaire to respondents consisting of private or 
industrial companies, university and the government ( $\mathrm{n}=18$ respondents) using an online questionnaire using a Likert scale from 1 to 5 (strongly disagree to strongly agree). Respondents selected are respondents who have a relationship with battery development in particular and are related to electric vehicle in general. Secondary data were obtained through literature studies in the form of national and international journals, standard documents and various other sources. The data obtained were analyzed descriptively to determine the readiness of infrastructure in terms of stakeholder needs for the proposed battery swap parameters for electric vehicles. The research framework is shown in Figure 2 below.

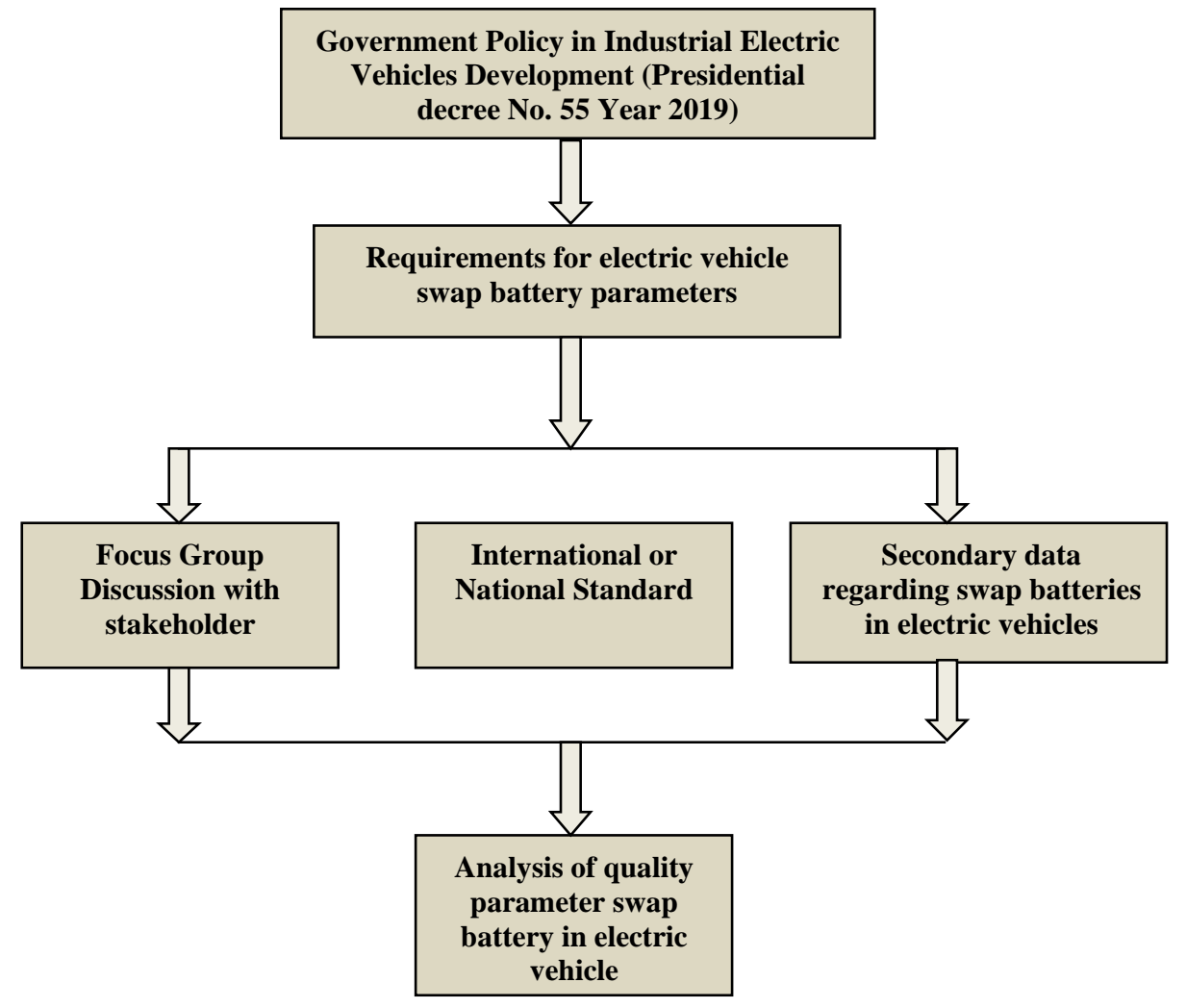

Figure 2. Research framework

\section{RESULTS AND DISCUSSION}

The research was conducted on respondents who are related to the development of swap batteries or electric vehicles that are developing swap batteries. As many as $50 \%$ of respondents are developers because this battery exchange system is being developed in Indonesia and requires a standard so that the exchanged batteries can be compatible with their electric vehicles. From a total of 18 respondents, 26\% have not developed swap batteries but most of them plan to develop swap batteries in the next five years (2020-2025). Respondents consisted of $50 \%$ developers, $17 \%$ producers, $17 \%$ developers and producers, $11 \%$ developers and users, and 5\% others (Figure 3). With various selected respondents consisting of various stakeholders, the proposed parameters are expected to answer the needs of the standard parameters of electric vehicle batteries in Indonesia.
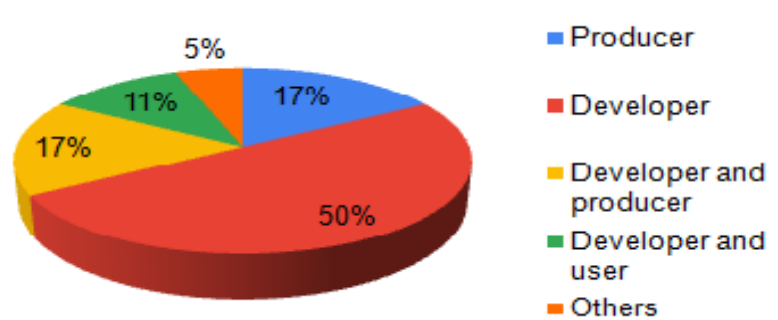

Figure 3. Types of research respondents 
In a swap battery swap system, several parameters are important to pay attention to. In Indonesia, the types of electric vehicle batteries used vary. $26 \%$ of respondents are developing/producing/using Lithium ferro phosphate (LFP) and lithium nickel manganese cobalt oxide (NMC) batteries, followed by $18 \%$ of respondents developing/producing/using lithium nickel cobalt alumunium oxide batteries (NCA), each $11 \%$ of respondents are developing/producing/using types of $\mathrm{Pb}$-acid batteries ( $\mathrm{Pb}$-acid) and other types of batteries and as many as $8 \%$ of respondents are developing/producing/using types of batteries Lithium manganese oxide (LMO) (Figure 4).

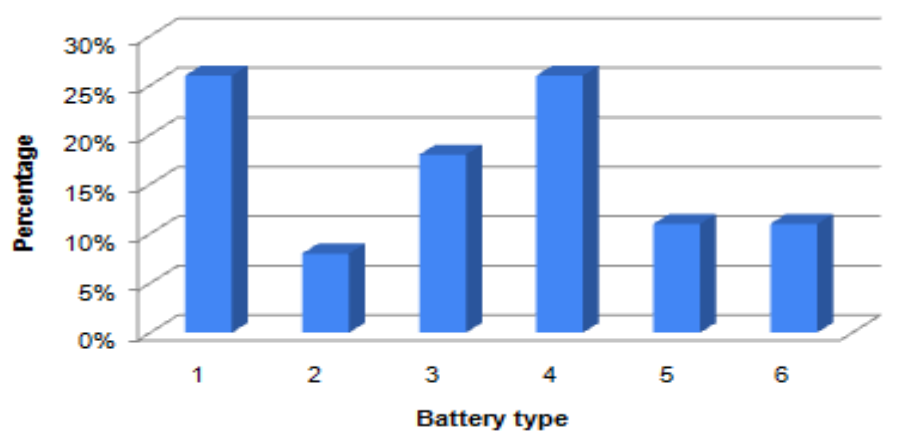

Figure 4. Battery type: 1. Lithium ferro phosphate (/LFP) 26\%; 2. Lithium manganese oxide (LMO) $8 \% ; 3$. Lithium nickel cobalt alumunium oxide (NCA) 18\%; 4. Lithium nickel manganese cobalt oxside (NMC) 26\%; 5. Pb-acid (Pb-acid) $11 \%$; 6. Others $11 \%$

The high use of lithium type batteries is based on several advantages, namely having large power, large energy density, and long service life so that lithium batteries are very attractive for use in various applications [12]. Batteries with NMC cathode materials have specific energy height and excellent thermal characteristics that are widely used in electric vehicles, including the Nissan Leaf, Chevy Volt, and BMW i3 [13]. Asection from batteries with NMC material, Lithium Iron Phosphate batteries are also widely used. Lithium Iron Phosphate (LFP) is a type of material used in almost all types of Li-ion batteries, the advantage of the LFP material at the cathode is that it gives the battery the ability to maintain a constant discharge process [14]. The weakness of batteries with LFP material is their low electrical conductivity, but this can be overcome by using activated carbon so that it can increase its conductivity properties [15]. The use of NCA batteries because they have a high capacity and density so that they can be applied to electric vehicles.

In addition to the type of battery, several parameters were tested using a Likert scale. Based on the results of data processing from respondents consisting of various related stakeholders with a value of more than $75 \%$, it needs to be considered. The value of $75 \%$ is the set limit value. The parameters tested that have a value equal to or more than $75 \%$ are size and dimensions, security system requirements, communication, protection against electric shock, equipment construction requirements, electromagnetic compatibility, and markings and instructions (Figure 5).

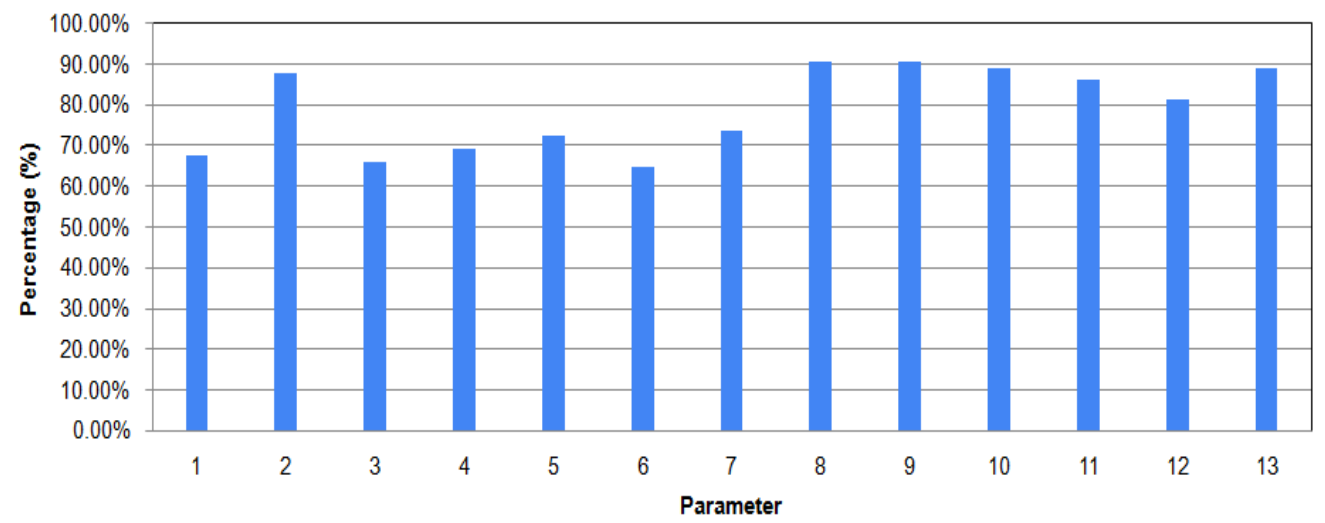

Figure 5. Percentage of battery parameters: 1. Capacity; 2. Size and dimension; 3. Power density; 4. Energy density; 5. Charging speed; 6. Battery mass; 7. Power rating; 8. Safety requirements of systems (IEC 628402:2016 Section 5); 9. Communication (IEC 62840-2:2016 Section 6); 10. Protection against electric shock (IEC 62840-2:2016 Section 7); 11. Equipment construction requirements (IEC 62840-2:2016 Section 8); 12. Electromagnetic compatibility (IEC 62840-2:2016 Section 9); 13. Marking and instructions (IEC 628402:2016 Section 10). 
One of the parameters that are considered important in a swap battery system is the size and dimensions of the battery, with a response of more than $75 \%$, which is $87.69 \%$. The sizes and dimensions of electric vehicle models vary so that it will have implications for the application of the swap battery system (Table 1). A case study at the Battery Swapping Station (BSS) charging station at Tesla, that the electric car swap battery system requires a BSS compatible battery architecture requirement that is compatible with the Tesla model and a large battery volume size will be difficult if it does not use automation technology [11]. One of the S-models from Tesla has a volume of about $400 \mathrm{~L}$ with a mass of $625 \mathrm{~kg}$, in contrast to the Nissan LEAF model which has a volume of $494 \mathrm{~L}$ and a mass of around $294 \mathrm{~kg}[16,17]$. Unlike the case with twowheeled vehicles, the bicycle model e-bike can have a volume of 1.39-2.30 L, and the scooter model is approximately 4-18 L and has a tendency to be portable [18]. Based on this, the size and dimension parameters affect the possibility of applying the swap battery system to the type of vehicle and can be considered batteries of various sizes that can be exchanged so as to facilitate the needs of industry in Indonesia.

Table 1. Size and dimension comparison of various electric vehicle models

\begin{tabular}{|c|c|c|c|c|c|c|}
\hline Vehicle models & Manufacture & Country & Battery type & Mass $(\mathrm{Kg})$ & Volume (L) & Source \\
\hline \multirow{3}{*}{ Bicycle } & Ritar & China & VRLA & 4.4 & 1.39 & \multirow{3}{*}{ [18] } \\
\hline & Panasonic & China & VRLA & 6.6 & 2.30 & \\
\hline & Panasonic & China & Li-ion & 2 & - & \\
\hline \multirow[t]{2}{*}{ Scooter } & $\begin{array}{c}\text { General } \\
\text { spesifications of } \\
\text { swap batteries }\end{array}$ & Taiwan & Li-ion & $<10$ & 4.1 & [19] \\
\hline & Gesits & Indonesia & Li-ion & 9 & 17.76 & Respondent \\
\hline \multirow[t]{2}{*}{ Car } & $\begin{array}{l}\text { Nissan (LEAF } \\
\text { Model) }\end{array}$ & Jepang & Li-ion & 294 & 494 & [16] \\
\hline & Tesla (Model-S) & Amerika & Li-ion & 625 & 400 & [17] \\
\hline
\end{tabular}

Two-wheeled vehicles have a greater potential to implement a swap battery system because of their relatively smaller size and dimensions compared to electric cars. This is also supported by the swapped battery automation technology in Indonesia so far there is still no, so the application of swap batteries manually with human power is more ideal for two wheels. Examples of two-wheeler applications have been carried out in Taiwan by applying the general specifications of the scooter model two-wheel swap batteries including the dimensions of the battery pack by the Taiwan Environmental Protection Agency (EPA) in 2014. The application of general specifications can encourage the accelerated change of conventional vehicles to electric vehicles [19].

Determining general specifications in Indonesia will certainly pose its challenges because it will involve local and foreign industries. The raw material for battery cells that cannot be produced nationally causes the size and dimensions to be influenced by the type of imported battery cells obtained by the industry. The battery cell is the smallest constituent size of a battery pack [20]. One respondent mentioned that one of the dimensions that had been designed had a volume of $17.76 \mathrm{~L}$ (Table 1). If the general Taiwan specifications are applied in Indonesia, the volume of the battery is four times larger than the Taiwan model, so the battery model still needs to be adjusted, even though it has the right mass. Volume is a secondary factor in battery capacity and determines the storage space for electric vehicles [18]. This is the case from one industry and there are still many other two-wheeled electric vehicle industries that need to be considered. Standard battery size and dimensions need to be considered together with stakeholders between regulators and related industries in the successful implementation of the battery swap.

In addition to the size or dimensions of the battery, several other parameters, which are related to the IEC 62840-2: 2016 standard, are considered to be considered as parameters for the quality requirements of developing swap battery standards. IEC 62840-2: 2016 describes in more detail about safety requirements. Each percentage based on its Likert scale is that it meets the requirements of the security system (IEC 628402: 2016 Section 5) 90.77\%, communication (IEC 62840-2: 2016 Section 6) 90.77\%, protection against electric shock (IEC 62840-2: 2016 Section 7) 89.23\%, equipment construction requirements (IEC 62840-2: 2016 Section 8) 86.15\%, electromagnetic compatibility (IEC 62840-2: 2016 Section 9) 81.54\% and marking and instructions (IEC 62840-2: 2016 Section 10) 89.23\%. Some of these parameters are also in accordance with the research the results of their research show that swap batteries require about 4 types of measurements or tests, including protection against electric shock, equipment construction requirements, electromagnetic capabilities and marking and instructions [7]. The requirements of stakeholder are converted into technical analysis; the equipment construction requirements are expected to have a heating and ventilation system, the equipment construction requirements are expected to be installed under the charging rack to avoid loss of battery efficiency when recharging and also the nominal battery exchange capacity can be adjusted as needed, on electromagnetic compatibility adjusting the speed of the current to the actual battery capacity and in the marking and instructions section sees the distance to one charge [7]. The four tests are contained in the 
IEC 62840-2: 2016 standard. The comparison used the IEC 62840-2: 2016 standard based on the availability of international standards that apply globally to battery exchange.

In addition to the parameters that have been described, here are some parameters that need to be considered and need to be further investigated about the parameters for the quality requirements of developing swap batteries in electric vehicles. Some of these parameters are the battery operating temperature and the standard for BMS. The operating temperature of the battery is considered important because it can discharge power (during startup and acceleration). Temperature and humidity levels greatly affect the performance, safety, and lifetime of battery cells, thus making control of them a major challenge for battery integration into vehicles [21]. In addition, the battery management system (BMS) is essential for battery electric vehicles (BEV) due to the fragility of lithium-ion batteries. The BMS is designed to monitor and protect the battery to improve performance and extend its cycle life [22]. Battery life can be extended to some extent by limiting the number of charges or discharge cycles [23]. In addition to temperature and standards for BMS, several other parameters are considered to be considered, namely chemical hazards, charging current and battery voltage, barcode scans that can display the performance of the battery so that it will make it easier for the battery exchange system, as well as the type and electronic specifications. Regarding the swap battery application system, the microgrid scheduling model can be effectively used in managing the operating system on the BSS so that it can provide economic benefits and efficiency when exchanging batteries [23].

\section{CONCLUSION}

Based on the research results, several parameters were obtained related to the quality requirements for the development of a national standard battery swap in electric vehicles, namely the type of battery, the size and dimensions of the battery, and fulfilling the requirements according to IEC 62840-2: 2016 Electric vehicle battery swap system - Safety requirements, namely related safety requirements of systems, communication, protection against electric shock, equipment constructional requirements, electromagnetic compatibility, and marking and instructions. It is hoped that these parameters can be taken into consideration for inclusion in the Indonesian National Standard governing battery exchange in electric vehicles. In addition, several other parameters need further research related to battery operating temperature, BMS, chemical hazards, battery charging current and voltage, barcode scanning, and the type and type of electronics.

\section{ACKNOWLEDGMENTS}

The author would like to thank the Center of Research and Human Resources Development of BSN who have provided funding allocations for this research through the DIPA. The author also expresses his deep gratitude to Mr. Budhy Basuki for the knowledge and time given during the process of writing articles. Also, the author would like to thank the colleagues of the Center of Research and Human Resources Development for their time and willingness to provide corrections, suggestions and knowledge that are very useful so that this article can be well structured and thanks to PT Gesit Technologies Indo and PT Nipress Tbk for being willing to visit us.

\section{REFERENCES}

[1] R. Ganter, C. Berrisford, Smart Mobility; UBS Chief Investment Office Americas, New York:USA, Wealth Managemen. 2017.

[2] A. Boulanger, A. Chu, S. Maxx and D. Waltz, "Vehicle Electrification: Status and Issues" Proceedings of The IEEE, Vol. 99, No. 6, pp. 1116-1138, 2011.

[3] Y. Song, J. Li, G. Ji, and Z. Xue, "Study on The Typical Mode EV Charging and Battery Swap Infrstructure Interconnecting to Power Grid," China International Conference on Electric Distribution, pp. 1-4, 2016.

[4] A. Ahmad, Z. Khan, M. Alam, and S. Khateeb, "A Review of The Electric Vehicle Charging Techniques, Standards, Progression and Evolution of EV Technologies in German" Smart Science, vol. 6, no. 1, pp. 36-53, 2018.

[5] M. Aziz, Y. Marcellino, , I. A. Rizki, S. A. Ikhwanuddin, and J. W. Simatupang, "Studi Analisis Perkembangan Teknologi Dan Dukungan Pemerintah Indonesia Terkait Mobil Listrik,” Tesla: Jurnal Teknik Elektro, vol. 22, no.1, pp. 454-55, 2020.

[6] F. A. Farizy, D.A. Asfani, and Soedibjo, "Desain Sistem Monitoring State of Charge Baterai pada Charging Station Mobil Listrik Berbasis Fuzzy Logic Dengan Mempertimbangkan Temperature, ” Jurnal Teknik ITS, vol. 5, no. 2, pp 2337-35539, 2016.

[7] D. Prianjani, W. Sutopo, E. Pujiyanto and F. Fahma, "Designing framework for standardization and testing requirements of battery swap for electric motorcycle application in Indonesia," International Journal of Applied Science and Engineering, vol. 15 no.2, pp. 141-148, 2018.

[8] Statistics Indonesia, "Jumlah kendaraan bermotor," 2019. 
[9] S. Shao, S. Guo, X. Qiu, "A mobile battery swapping service for electric vehicles based on a battery swapping van," Energie, vol. 10, pp. 1-21, 2017.

[10] H. Y. Mak, Y. Rong and Z. Shen, "Infrastructure planning for electric vehicles with battery swapping," Management Science, vol. 59, no. 7, pp. 1557-1575, 2013.

[11] F. Adegbohun, A. V. Jouanne, and K.Y. Lee, "Autonomous Battery Swapping System and Methodologies of Electric Vehicles," vol 12, pp.1-14, 2019.

[12] S.U. Muzayanha, C.S. Yudha, L.M Hasanah, A. Nur, A. Purwanto, "Pengaruh pemanasan pada proses pretreatment untuk daur ulang material katoda betarei Li-ion," Jurnal Kimia dan Pendidikan Kimia, vol. 4, no.2, pp. 105-114, 2019.

[13] Y. Miao, P. Hynan, A. V. Jouanne, A. Yokochi, "Current Li-ion battery technologies in electric vehicles and opportunities for advancements," Energies, vol. 12, pp. 1-20, 2019.

[14] G. StewartS, V. Srinivasan, J. Newman, "Modeling the performance of lithium-ion batteries and capacitors during hybrid-electric-vehicle operation," Journal of the Electrochemical Society, vol. 155, no. 9, pp. A664-A671, 2008.

[15] Junaidi, K.H. Khwee, A. Hiendro, "Migrai baterai lithium dari mode otomotif ke mode penyimpanan energy untuk sisstem pembangkit listrik tenaga sury," Jurnal Elkha, vol. 8, no. 2, pp. 40-43, 2016.

[16] Tesla, Running change to add Model S 100D and New $75 \mathrm{kWh}$ FW limited battery pack configuration, Washington DC: US EPA, 2017.

[17] Nissan, Nissan 2011 LEAF First Responder's Guide, Tokyo: Nissan. 2011.

[18] J. X. Weinert and A. F. Burke, "Lead-acid and Lithium-ion batteries for electric bikes in China: Implications on the future growth of electric-drive vehicles," eceee 2007 Summer Study on energy efficiency: Saving energy - Just do it, pp. 1801-1810, 2007.

[19] S.H. Suen, B.M. Lin, and J. S. C. Jang, "Strategy and Construction of Electric Refueling System for Electric Scooter in Taiwan. EVS27," International Battery, Hybrid and Fuel Cell Electric Vehicle Symposium, pp. 1-6, 2013.

[20] E, Maiser, "Battery Packaging - Technology Review," AIP Conference Proceedings 1597, vol. 204, pp. 204-218, 2014.

[21] C. Huber and R. Kuhn, "Thermal management of batteries for electric vehicles," in Advances in Battery Technologies for Electric Vehicles, 2015, Woodhead Publishing, pp. 327-358.

[22] T. Zhou, "Design and development of a modular battery management system for battery electric vehicle," M.S. thesis, Hong Kong University of Science and Technology, Hongkong, 2014.

[23] Y. Li, Z. Yang, G. Li, Y. Mu, D. Zhao, C. Chen and B. Shen, "Optimal scheduling of isolated microgrid with an electric vehicle battery swapping station in multi-stakeholder scenarios: A bi-level programming approach via realtime pricing,“'Applied Energy, vol. 232, pp. 54-68, 2018.

\section{BIOGRAPHY OF AUTHORS}

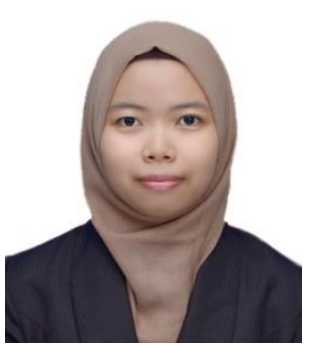

Widia Citra Anggundari was born in Sukabumi on July 28, 1992. The author completed her Diploma majoring in Chemical Analysis at IPB University and graduated in 2013, then continued her undergraduate degree majoring in Chemistry at IPB University and graduated in 2015. Currently, the author is working at the National Standardization Agency of Indonesia as assistant researcher.

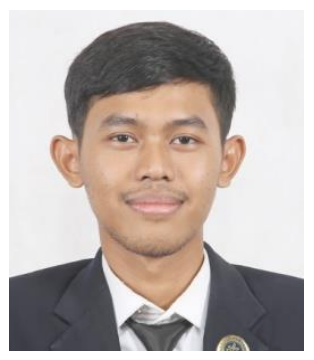

Auraga Dewantoro was born in Tangerang, May 3 1995. The authors completed his undergraduate degree majoring in Silviculture at IPB University and graduated in 2018. Currently, the author is working at the National Standardization Agency of Indonesia as assistant researcher.

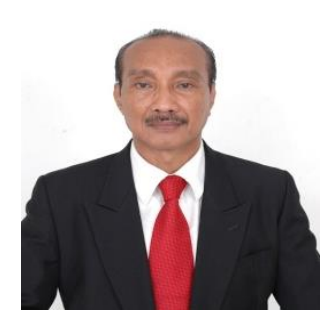

Bendjamin B. Louhenapessy was born in Tuhaha November 17, 1960. The author completed his undergraduate degree majoring in Chemical Engineering at Hasanuddin University and graduated in 2015, then continued his master degree in Coorporate Law at 17 Agustus 1945 University in 2010. Currently, the author is working at the National Standardization Agency of Indonesia as a senior researcher. 


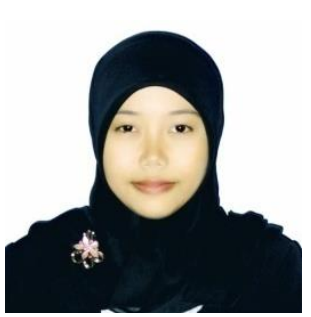

Rika Dwi Susmiarni was born in Palembang on March 24, 1990. The author completed her undergraduate degree majoring in Marine Science at Sriwijaya University and graduated in 2013. Currently, the author is working at the National Standardization Agency of Indonesia as a data analyst.

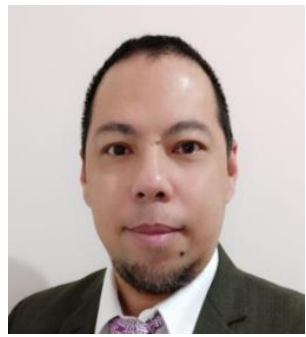

Yopi was born in Desember 20, 19609 The author completed his undergraduate degree majoring in Applied Biological Science / Biotechnology, Tokyo University of Agriculture and Technology in 1994, then continued his master degree in Applied Biological Science / Biotechnology, Tokyo University of Agriculture and Technology, and grant $\mathrm{PhD}$. Degree in Applied Biological Chemistry / Biotechnology at 2002. Coorporate Law at 17 Agustus 1945 University in 2010. Currently, the author is working at the National Standardization Agency of Indonesia as a Head of Center of Research and Human Resources Development..

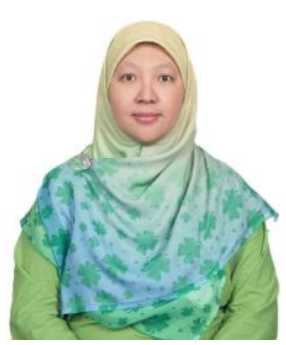

Nur Tjahyo Eka Darmayanti was born in Jakarta on May 26, 1977. The author completed her undergraduate degree majoring in Physics at University of Indonesia and graduated in 1999, then continued her master degree in Material Science at University of Indonesia. Currently, the author is working at the National Standardization Agency of Indonesia as a Head of research dissemination of standardization and conformity assessment. 